\title{
The Mode of Action of Nosiheptide (Multhiomycin) and the Mechanism of Resistance in the Producing Organism
}

\author{
By ERIC CUNDLIFFE* AND JILL THOMPSON \\ Department of Biochemistry, University of Leicester, Leicester LE1 7RH, U.K.
}

(Received 11 December 1980)

The mode of action of nosiheptide (multhiomycin) on bacterial protein synthesis is closely
similar to that of thiostrepton. Both antibiotics inhibit functions of elongation factors Tu and
$G$ and greatly reduce the synthesis of guanosine penta- and tetraphosphates in response to
stringent factor. Furthermore, the actinomycetes which produce these antibiotics defend
themselves against their products in similar fashion. This involves specific pentose-
methylation of $23 \mathrm{~S}$ ribosomal RNA.

\section{IN TRODUCTION}

A number of sulphur-containing polypeptide antibiotics selectively inhibit protein synthesis in bacterial extracts, although some of them fail to penetrate Gram-negative cells. Among such agents are thiostrepton, siomycin, sporangiomycin and thiopeptin (the thiostrepton group' of antibiotics) which are closely related in structure and possess apparently identical modes of action (for a review, see Cundliffe, 1980). In contrast, other sulphur-containing peptides such as althiomycin, thermothiocin and actinotiocin which have, on occasion, been compared with thiostrepton (Tamura et al., 1973) are now known to act differently (Pestka \& Brot, 1971; Cundliffe \& Dixon, 1975).

Multhiomycin, produced by Streptomyces antibioticus (Tanaka et al., 1970a), has recently been shown to be identical to nosiheptide, the product of Streptomyces actuosus, and to be related in structure to thiostrepton - not least to the extent that both molecules contain five thiazole rings (Prange et al., 1977). To date, relatively little has been reported concerning the action of this compound; however, multhiomycin selectively inhibited protein synthesis in intact cells of Bacillus subtilis and in extracts of Escherichia coli (Tanaka et al., 1970 b). It also seemed clear from these studies that multhiomycin probably acted by binding directly to ribosomes. Closer examination revealed that the drug inhibited partially the enzymic binding of aminoacyl-tRNA to the [ribosome-mRNA] complex together with the associated hydrolysis of GTP, but only when present at quite high molar excess over ribosomes (Tanaka et al., 1971). Since thiostrepton group antibiotics also act in this way, in addition to affecting other partial reactions of protein synthesis, we have examined further the mechanism of action of nosiheptide (multhiomycin) and compared its effects with those of thiostrepton. Actinotiocin and thermothiocin, about whose modes of action little is known, were also included in various assays.

Actinomycetes which produce thiostrepton, siomycin or sporangiomycin defend themselves against their products via similar patterns of post-transcriptional modification of ribosomal RNA (rRNA). Thus, methylation at a single site within 23S rRNA leads to ribosomes which are refractory to the action of these drugs and to which $\left[{ }^{35} \mathrm{~S}\right]$ thiostrepton does not bind detectably (Cundliffe, 1978; Thompson \& Cundliffe, 1980). The methylated residue implicated in this mode of self-defence is $2^{\prime}-O$-methyladenosine (Cundliffe \& Thompson, 1979). However, such ribosomes remain sensitive to the action of actinotiocin, thermothiocin 
and other antibiotics not belonging to the thiostrepton group (E. Cundliffe \& J. Thompson, unpublished data). Accordingly, we wished to determine whether pentose-methylated ribosomes are also resistant to nosiheptide and whether $S$. actuosus utilizes a similar mechanism of resistance to its product.

\section{METHODS}

Preparation of E. coli ribosomes and sub-ribosomal core particles. Methods for the preparation of salt-washed ribosomes and post-ribosomal supernatant $(\mathrm{S} 100)$ and their utilization in polyphenylalanine synthesis in response to polyuridylic acid [poly(U)] have been described in full elsewhere (Cundliffe et al., 1979). The preparation of core particles and 'split proteins' by exposure of ribosomes to $\mathrm{LiCl}$ (here we used $3 \mathrm{M}$ - $\mathrm{LiCl}$ ) was as described, except that split proteins were concentrated and stored in 'reconstitution buffer' [containing $20 \mathrm{~mm}$ - Tris/ $\mathrm{HCl}$

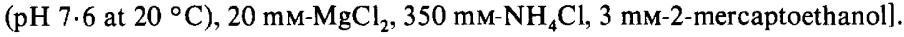

Methylation of core particles and re-addition of split proteins. The $3 \mathrm{M}-\mathrm{LiCl}$ core particles from $E$. coli ribosomes $(126 \mathrm{pmol})$ were incubated at $35^{\circ} \mathrm{C}$ with $S$. actuosus $\mathrm{S} 100(60 \mu \mathrm{l}$; arbitrary amount) in $210 \mu \mathrm{l}$ buffer (containing $50 \mathrm{mM}-\mathrm{N}$-2-hydroxyethylpiperazine- $N^{\prime}$-2-ethanesulphonic acid (HEPES)/KOH $\left(\mathrm{pH} 7.5\right.$ at $20^{\circ} \mathrm{C}$ ), $10 \mathrm{mM}-\mathrm{MgCl}_{2}, 50 \mathrm{mM}-\mathrm{NH}_{4} \mathrm{Cl}, 3 \mathrm{~mm}$-2-mercaptoethanol] in the presence and absence of $S$-adenosylmethionine (SAM; $0.5 \mathrm{mM})$. At intervals, samples $(50 \mu \mathrm{l})$ containing 30 pmol cores were mixed with $30 \mu \mathrm{l}(96 \mathrm{pmol}$ equivalents) $3 \mathrm{M}-\mathrm{LiCl}$ split proteins and incubation was continued at $20^{\circ} \mathrm{C}$ for $10 \mathrm{~min}$. One pmol equivalent of split proteins is defined as those proteins released from one pmol $70 \mathrm{~S}$ ribosomes during their conversion to core particles.

Binding of $\left[{ }^{35} S\right]$ thiostrepton to reconstituted ribosomal particles. This was carried out essentially as described elsewhere (Thompson et al., 1979). Radiolabelled drug (39 pmol; 480 c.p.m. pmol $^{-1}$ ) was added directly to reconstitution mixtures containing $30 \mathrm{pmol} 3 \mathrm{M}-\mathrm{LiCl}$ core particles and $96 \mathrm{pmol} 3 \mathrm{M}$ - $\mathrm{LiCl}$ split proteins, as above. Incubation was continued at $20^{\circ} \mathrm{C}$ for $10 \mathrm{~min}$ before $10 \mu \mathrm{l}$ of $5 \%(\mathrm{w} / \mathrm{v})$ suspension of activated charcoal ('Norit') was added to adsorb unbound drug. After $5 \mathrm{~min}$ at $20^{\circ} \mathrm{C}$, charcoal was removed by centrifugation at $12000 \mathrm{~g}$ for $2 \mathrm{~min}$ and ribosome-bound thiostrepton in the supernatant was estimated by liquid-scintillation spectrometry.

Uncoupled hydrolysis of GTP by ribosomes and elongation factor EF-G. Reaction mixtures (75 $\mu$ ) contained $2.4 \mathrm{pmol} 70 \mathrm{~S}$ ribosomes from $E$. coli together with $50 \mathrm{pmol}$ factor EF-G and $9 \mathrm{nmol}\left[\boldsymbol{\gamma}^{32} \mathrm{P}\right] \mathrm{GTP}[62.3 \mu \mathrm{Ci}$ $\mu \mathrm{mol}^{-1}\left(2.305 \mathrm{MBq} \mu \mathrm{mol}^{-1}\right)$, i.e. approximately 135 c.p.m. $\mathrm{pmol}^{-1}$ in buffer [containing $15 \mathrm{~mm}-\mathrm{Tris} / \mathrm{HCl}(\mathrm{pH}$

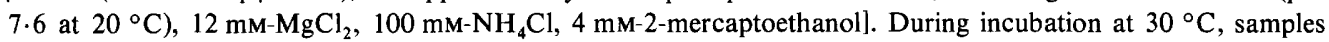
$(20 \mu \mathrm{l})$ were removed at intervals into $20 \mu \mathrm{l}$ ice-cold $1 \mathrm{M}$-perchloric acid to terminate hydrolysis. Unhydrolysed, radioactive GTP was removed by addition of $200 \mu \mathrm{l}$ of $5 \%(\mathrm{w} / \mathrm{v})$ suspension of activated charcoal ('Norit') in water followed by centrifugation at $12000 \mathrm{~g}$ for $2 \mathrm{~min}$ to remove both the charcoal and the macromolecular precipitate. Radioactivity ([ $\left.{ }^{32} \mathrm{P}\right]$ phosphate) in the supernatant was estimated by liquid-scintillation spectrometry. Purified factor EF-G from E. coli was a kind gift from Professor James Bodley, Department of Biochemistry, University of Minnesota, Minneapolis, U.S.A.

Synthesis of guanosine penta- and tetraphosphates in vitro. This was carried out using $70 \mathrm{~S}$ ribosomes, unfractionated tRNA and crude stringent factor (all from $E$. coli) together with poly(U), GTP and $\left[\gamma^{-32}\right.$ P]ATP (80 c.p.m. pmol $^{-1}$ ) as described elsewhere (Stark \& Cundliffe, 1979a). Crude stringent factor was prepared by ammonium sulphate fractionation of a $1 \mathrm{M}-\mathrm{NH}_{4} \mathrm{Cl}$ ribosomal wash according to Block \& Haseltine (1975). Reaction mixtures were incubated at $37^{\circ} \mathrm{C}$ for $40 \mathrm{~min}$ before nucleotide products were separated by chromatography on poly (ethyleneimine)-cellulose plates and located by autoradiography overnight. Radioactivity incorporated into guanosine penta- and tetraphosphates was determined by cutting out appropriate pieces of the chromatogram followed by liquid-scintillation spectrometry (for details see Stark \& Cundliffe, 1979a).

Cell-free protein synthesis in extracts of actinomycetes. The growth and extraction of actinomycetes and the preparation of salt-washed ribosomes and S100 suitable for the study of polyphenylalanine synthesis in vitro have recently been described (Thompson \& Cundliffe, 1980).

Preparation and characterization of $\left[{ }^{35} S\right]$ nosiheptide. Spores of Streptomyces actuosus NRRL 2954 were used to inoculate $50 \mathrm{ml}$ of medium containing (per litre) $10 \mathrm{~g}$ peptone, $15 \mathrm{~g}$ malt extract, $20 \mathrm{~g}$ glucose, $3 \mathrm{~g}$ yeast extract and $20 \mathrm{~g}$ maltose. After $2 \mathrm{~d}$ at $30^{\circ} \mathrm{C}, 3.5 \mathrm{mCi}(130 \mathrm{MBq})$ carrier-free $\left[{ }^{35} \mathrm{~S}\right]$ sulphate was added followed $1 \mathrm{~d}$ later by a similar addition. Incubation was continued at $30^{\circ} \mathrm{C}$ with gentle shaking until, after $8 \mathrm{~d}$ in the presence of $\left.{ }^{[35} \mathrm{S}\right]$ sulphate, the whole culture was extracted repeatedly by shaking with chloroform. The extract was taken down to a small volume by rotary flash evaporation at $37^{\circ} \mathrm{C}$ and passed twice over a Whatman DE 52 column $(5 \times$ $1 \mathrm{~cm}$ ) in chloroform. This removed brown material together with about one-third of the radioactivity. After drying the eluate, crude $\left.{ }^{35} \mathrm{~S}\right]$ nosiheptide was taken up in dimethyl sulphoxide leaving about $25 \%$ of the radioactivity in the form of a waxy residue. Of the radiolabelled material in this preparation, about $70 \%$ bound to $E$. coli ribosomes and, of this, two-thirds was evidently $\left[{ }^{35}\right.$ S $]$ nosiheptide: its binding to $E$. coli ribosomes was competitive with that of authentic nosiheptide and it did not bind detectably to ribosomes of $S$. actuosus. In 
contrast, the remaining one-third of the ribosome-binding material attached equally well to ribosomes from both organisms and such 'non-specific' binding was not prevented by prior addition of nosiheptide. The specific radioactivity of $\left[{ }^{35} \mathrm{~S} /\right.$ nosiheptide was established in the usual way by dilution with authentic drug (which was assumed to be $100 \%$ pure) followed by ribosome-binding studies. The initial specific radioactivity was close to 400 c.p.m. pmol $^{-1}$, the apparent stoichiometry of binding to $E$. coli ribosomes was close to $1: 1$ and the total yield of $\left.{ }^{35} \mathrm{~S}\right]$ nosiheptide was approximately $300 \mathrm{nmol}$ (about $370 \mu \mathrm{g}$ ). In all these experiments, binding of drug to ribosomes was determined following the removal of unbound material by adsorption to activated charcoal as above (see also Thompson et al., 1979).

Binding of $\left[{ }^{35} S\right]$ nosiheptide to $R N A$-protein complexes. Complexes were formed between purified $E$. coli $23 \mathrm{~S}$ rRNA (52 pmol), or total RNA from 70 S ribosomes $(52 \mathrm{pmol})$, and ribosomal protein L11 (186 pmol) by incubating them together for $10 \mathrm{~min}$ at $20^{\circ} \mathrm{C}$ as described elsewhere (Thompson et al., 1979) except that here the buffer contained $10 \mathrm{mM}-\mathrm{MgCl}_{2}$. Then, $\left[{ }^{35} \mathrm{~S}\right.$ ]nosiheptide (approximately $120 \mathrm{pmol}$ in $5 \mu$ dimethyl sulphoxide) was added for a further $10 \mathrm{~min}$ at $20^{\circ} \mathrm{C}$. The final incubation volume was $100 \mu$ l. Subsequently, unbound drug was removed by adsorption to activated charcoal followed by centrifugation (see Thompson et al., 1979). Complexes of rRNA with protein L11 evidently bound both nosiheptide and some other unidentified material present in the radiolabelled drug preparation. Specific binding of $\left[{ }^{35}\right.$ S Inosiheptide was dependent upon the presence of both $23 \mathrm{~S}$ rRNA and protein L11 and was prevented by prior addition of authentic drug. Non-specific binding occurred to similar extents with RNA-L11 complexes, with rRNA alone (but not with protein L11 alone) and with $70 \mathrm{~S}$ ribosomes (see above). This background was subtracted from data presented in Table 2 and amounted to about one-third of the total when protein L11 was present.

Ribosomal protein L11 from E. coli was kindly provided by Dr Jan Dijk and was prepared according to Dijk \& Littlechild (1979).

\section{RES ULTS}

Nosiheptide is a potent inhibitor of protein synthesis in extracts of $E$. coli (Tanaka et al., $1970 \mathrm{~b}$ ). In our hands, following incubation with an equimolar amount of the drug, E. coli ribosomes were almost totally inhibited in polyphenylalanine synthesis in vitro (data not given). Ribosomes from Streptomyces coelicolor were equally sensitive to the drug (see below). In a further series of experiments, we confirmed earlier observations (Tanaka et al., 1971) that nosiheptide inhibits, albeit incompletely, the enzymic binding of phenylalanyltRNA to the [ribosome - poly(U)] complex. Our results are merely stated here (see Stark \& Cundliffe, $1979 b$, for details of methods). Thus, when present at 100 -fold molar excess over ribosomes, nosiheptide inhibited the enzymic binding reaction by about $30 \%$, in contrast to thiostrepton which inhibited binding by about $70 \%$ under similar conditions. We did not examine the hydrolysis of GTP which normally accompanies such binding; however, partial inhibition of this reaction by nosiheptide has also been reported (Tanaka et al., 1971).

Continuing our comparison of the effects of nosiheptide and thiostrepton, we examined ribosomal functions dependent upon factor EF-G. This protein functions in the complex translocation reaction of polypeptide chain elongation during which one molecule of GTP is hydrolysed per active ribosome. Neither factor EF-G nor the ribosome alone possesses GTPase activity but together, in vitro, they catalyse multiple rounds of GTP hydrolysis in a manner uncoupled from peptide chain elongation. Only antibiotics of the thiostrepton group have been shown to inhibit such uncoupled hydrolysis of GTP, hence we were particularly interested to examine nosiheptide in this system. As shown in Fig. 1, nosiheptide was, at best, a poor inhibitor of GTP hydrolysis. However, given that other inhibitors of protein synthesis, including actinotiocin and thermothiocin, routinely fail to inhibit this system to any detectable extent (Pestka \& Brot, 1971; also Fig. 1), the levels of inhibition (around 20\%) observed with nosiheptide appear significant.

A related assay, also inhibited exclusively by thiostrepton group antibiotics, involves the formation of [ribosome EF-G - guanine nucleotidel complexes and their stabilization in the presence of fusidic acid (Bodley et al., 1970; Weisblum \& Demohn, 1970). Such complexes can, in vitro, be formed directly either from GDP or from GTP in which case the latter is normally hydrolysed. Nosiheptide proved to be a potent inhibitor of the formation and/or stabilization of [ribosome $\cdot$ EF-G $\cdot$ guanine nucleotide] complexes, although not as effective as 


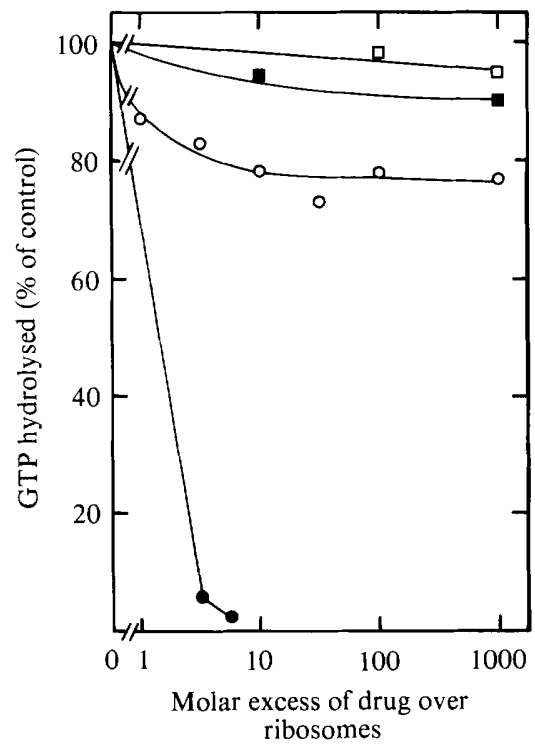

Fig. 1

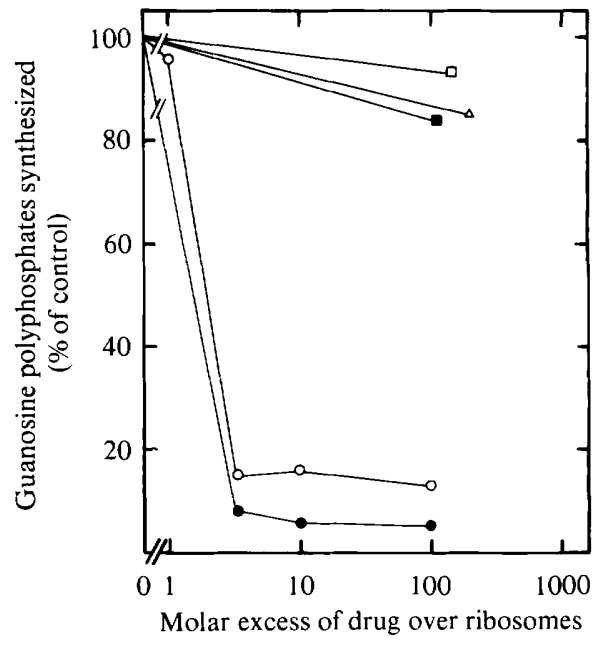

Fig. 2

Fig. 1. Uncoupled hydrolysis of GTP by ribosomes and factor EF-G in the presence of drugs. Ribosomes were incubated with drugs for $5 \mathrm{~min}$ at $30^{\circ} \mathrm{C}$ prior to addition of factor EF-G and $\left[\gamma^{32}\right.$ P]GTP. Hydrolysis of GTP was then followed over a 10 min time course as described in Methods. Data were computed for the end-points of such incubations, by which time, in controls, approximately 1350 pmol GTP had been hydrolysed per pmol ribosomes. Controls contained dimethyl sulphoxide (usually $1 \%, \mathrm{v} / \mathrm{v}$, final concentration) in which drug solutions were prepared. Drugs: 0 , thiostrepton; $O$, nosiheptide; $\mathbf{\square}$, thermothiocin; $\square$, actinotiocin.

Fig. 2. Synthesis of guanosine penta- and tetraphosphates in response to stringent factor in the presence of drugs. Ribosomes were incubated with drugs (dimethyl sulphoxide was added to controls) for $10 \mathrm{~min}$ at $20^{\circ} \mathrm{C}$ prior to addition of other assay components (see Methods). In controls, approximately $12 \%$ of the radioactivity added as $\left[\gamma^{32}\right.$ P $]$ ATP was incorporated into guanosine polyphosphates. Drugs: $\mathbf{O}$, thiostrepton; $O$, nosiheptide; $\mathbf{Q}$, thermothiocin; $\square$, actinotiocin; $\triangle$, bottromycin.

\section{Table 1. Effects of antibiotics on the formation of [ribosome $\cdot E F-G \cdot g u a n i n e ~ n u c l e o t i d e]$ complexes in the presence of fusidic acid}

Reaction mixtures contained 20 pmol $E$. coli ribosomes, 50 pmol factor EF-G, 100 pmol $\left[\right.$ ring- $\left.{ }^{3} \mathrm{H}\right] \mathrm{GTP}$ $\left(13.3 \mathrm{Ci} \mathrm{pmol}^{-1}\right)$ and $3 \mathrm{~mm}$-sodium fusidate; for details, see Stark \& Cundliffe $(1979 \mathrm{~b})$. Drugs were added in solution in dimethyl sulphoxide which was also included in controls.

\begin{tabular}{|c|c|c|c|}
\hline \multirow[b]{2}{*}{ Drug added } & \multirow{2}{*}{$\begin{array}{l}\text { Molar excess } \\
\text { of drug } \\
\text { over ribosomes }\end{array}$} & \multicolumn{2}{|c|}{$\begin{array}{l}\text { [Ribosome } \cdot \text { EF-G } \cdot \text { guanine nucleotide } \\
\text { complexes formed }\end{array}$} \\
\hline & & $\begin{array}{c}\text { pmol per } \\
100 \text { pmol ribosomes }\end{array}$ & $\%$ of control \\
\hline None & - & 63.8 & 100 \\
\hline Nosiheptide & $\begin{array}{c}3 \cdot 7 \\
37 \\
125 \\
800\end{array}$ & $\begin{array}{l}12 \cdot 4 \\
11 \cdot 9 \\
12 \cdot 4 \\
10 \cdot 5\end{array}$ & $\begin{array}{l}19.4 \\
18 \cdot 7 \\
19.4 \\
16 \cdot 5\end{array}$ \\
\hline Thiostrepton & $\begin{array}{l}3 \cdot 7 \\
37 \\
125 \\
600\end{array}$ & $\begin{array}{l}3 \cdot 6 \\
3 \cdot 5 \\
2 \cdot 8 \\
3 \cdot 1\end{array}$ & $\begin{array}{l}5 \cdot 6 \\
5 \cdot 5 \\
4 \cdot 4 \\
4 \cdot 9\end{array}$ \\
\hline
\end{tabular}




\section{Table 2. Binding of $\left[{ }^{35} S\right]$ nosiheptide to $R N A$-protein complexes}

Complexes were formed by incubating purified $E$. coli $23 \mathrm{~S}$ rRNA (52 pmol) or total RNA from $70 \mathrm{~S}$ ribosomes (RNA 70, $52 \mathrm{pmol}$ ) with $E$. coli ribosomal protein L11 (186 pmol). [ ${ }^{35}$ SlNosiheptide (120 pmol) was then added and its binding to the complexes was assayed. For details, see Methods.

$\begin{array}{lcc}\text { rRNA input } & \text { Protein L11 } & \begin{array}{c}{\left[{ }^{35} \text { S }\right] \text { osiheptide bound }} \\ (\mathrm{pmol})\end{array} \\ \text { 23S rRNA } & + & 56 \\ \text { RNA 70 } & + & 59 \\ \text { RNA 70 } & - & 0 \\ \text { RNA 70 } & + & 2^{*} \\ & * \text { Thiostrepton }(75 \mathrm{pmol}) \text { added prior to nosiheptide. }\end{array}$

thiostrepton (Table 1). Again, this indicates similarities in the action of the two drugs, particularly since the assay is unaffected by a large number of other antibiotics which inhibit protein synthesis (Pestka \& Brot, 1971; E. Cundliffe \& J. Thompson, unpublished observations) including actinotiocin and thermothiocin.

One further ribosomal reaction was examined and was found to be extremely sensitive to inhibition by nosiheptide. This involved the synthesis in vitro of the regulatory nucleotides guanosine penta- and tetraphosphates (the so-called 'magic spot' compounds) in response to stringent factor, mRNA and cognate deacylated tRNA. Pyrophosphate transfer from ATP to the $3^{\prime}$-hydroxyl of GTP or GDP occurs under such conditions in a reaction which appears to involve the ribosomal A site. Both thiostrepton and nosiheptide inhibited this reaction potently whereas other peptides such as actinotiocin, thermothiocin and bottromycin were virtually without effect (Fig. 2). Production of guanosine polyphosphates is inhibited by drugs such as chlortetracycline which prevent the binding of mRNA-cognate tRNA into the ribosomal A site (Pedersen et al., 1973). Hence, it is not clear from our data whether nosiheptide and thiostrepton act in that manner or whether they interfere directly with the binding or action of stringent factor.

From these results, we concluded that nosiheptide resembled thiostrepton in various aspects of its action but that, generally, thiostrepton acted more potently. In accord with this, nosiheptide proved to be a weak inhibitor of the binding of thiostrepton to $E$. coli ribosomes. However, when present at 1000 -fold molar excess over $\left[{ }^{35}\right.$ S $]$ thiostrepton, nosiheptide inhibited binding of the latter by $85-90 \%$ (data not given). The reciprocal experiments were more revealing. $\left[{ }^{35} \mathrm{~S}\right]$ Nosiheptide bound firmly to $E$. coli ribosomes (but not to those of $S$. actuosus) and such binding was powerfully inhibited by thiostrepton (data not given). Further, $\left[{ }^{35}\right.$ S $]$ nosiheptide bound stoichiometrically to the complex of $23 \mathrm{~S}$ rRNA with ribosomal protein L1 1 (Table 2), and thiostrepton, which also binds to such complexes, was again inhibitory.

These data were supported by the results of experiments with thiostrepton-resistant mutants of Bacillus megaterium, which lack a protein (designated BM-L11) normally present in the 50S ribosomal subunit (Cundliffe et al., 1979). Protein BM-L11 is the immunological and functional homologue of ribosomal protein L11 of $E$. coli. Since thiostrepton normally binds to the complex of 23S RNA with protein (BM) L11, ribosomes from the mutants bind the drug poorly in comparison with those from the wild-type. As expected from the data presented in Table 2, the thiostrepton-resistant mutants were cross-resistant to nosiheptide (data not given). Interestingly, however, they remained sensitive to actinotiocin and thermothiocin.

Since thiostrepton and nosiheptide evidently bound to related (or even identical) sites on the $E$. coli ribosome (albeit with differing affinity), we examined the ribosomes from the organisms which produce the two antibiotics. Initially, we observed that Streptomyces azureus (which produces thiostrepton) and Streptomyces actuosus (the nosiheptide producer) were unaffected by thiostrepton or nosiheptide when challenged on growth plates with 


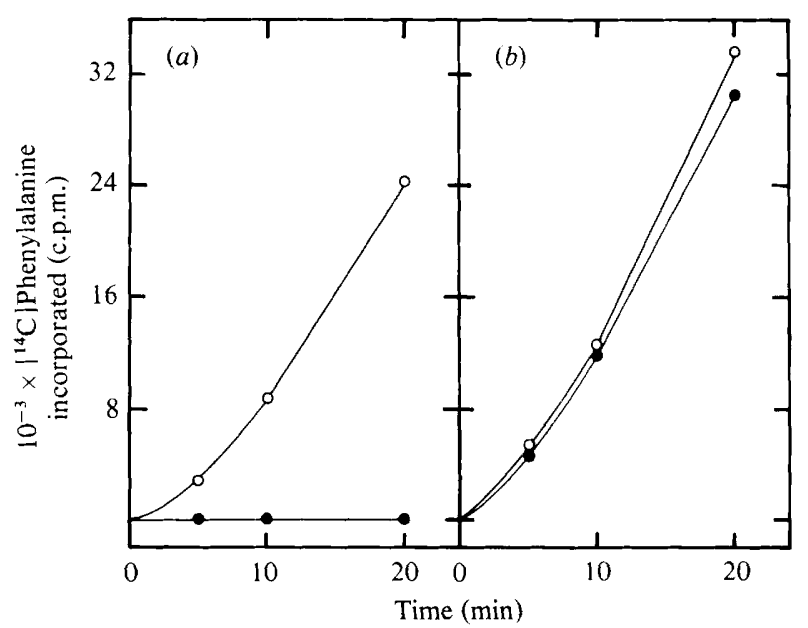

Fig. 3. Synthesis of polyphenylalanine by Streptomyces ribosomes in the presence and absence of drugs. Ribosomes from $S$. coelicolor $(a)$ or $S$. actuosus $(b)$ were incubated with drugs (dimethyl sulphoxide was added to controls) for $10 \mathrm{~min}$ at $30^{\circ} \mathrm{C}$ prior to the addition of other assay components. In each case post-ribosomal supernatant from $S$. coelicolor was employed. Samples contained 6 or 7 pmol ribosomes; $\left[{ }^{14} \mathrm{C} /\right.$ phenylalanine was used at a specific radioactivity of $513 \mathrm{mCi} \mathrm{mmol}^{-1}$ (about 1000 c.p.m. pmol-1 $)$. (a) O, control; O, plus thiostrepton $\left(100 \mu \mathrm{g} \mathrm{ml}^{-1}\right)$ or nosiheptide $\left(100 \mu \mathrm{g} \mathrm{ml}^{-1}\right)-$ effects indistinguishable; $(b) \mathrm{O}$, control or plus thiostrepton $\left(100 \mu \mathrm{g} \mathrm{m}^{-1}\right)$; $\mathrm{O}$, plus nosiheptide $(100 \mu \mathrm{g}$ $\mathrm{ml}^{-1}$ ).

\section{Table 3. Effects of methylation of E. coli ribosomal cores by $S$. actuosus extract}

Mixtures containing $3 \mathrm{M}-\mathrm{LiCl}$ core particles from $E$. coli ribosomes and $S$. actuosus $\mathrm{S} 100$ were incubated with or without SAM for the periods indicated. Samples were then mixed with $3 \mathrm{M}-\mathrm{LiCl}$ 'split proteins', and binding of $\left[{ }^{35} S \mid\right.$ thiostrepton to the reconstituted particles was assayed. For details, see Methods. In the absence of split proteins, binding of $\left[{ }^{35}\right.$ S $\mid$ thiostrepton to cores was 0.02 pmol per pmol.

$\begin{array}{ccc}\begin{array}{c}\text { Time of } \\ \text { incubation } \\ \text { (min) }\end{array} & \begin{array}{c}\text { Cofactor } \\ \text { (SAM) }\end{array} & \begin{array}{c}\left.{ }^{35} \text { S }\right] \text { Thiostrepton bound } \\ \text { (pmol per }\end{array} \\ 0 & - & 1.00 \\ 20 & + & 0.72 \\ 20 & - & 0 \cdot 89 \\ 45 & + & 0.57 \\ 45 & - & 0 \cdot 88 \\ 120 & + & 0.09 \\ 120 & - & 0.88\end{array}$

antibiotic assay discs (data not given). Subsequently, ribosomes from $S$. actuosus proved to be totally insensitive to either drug when synthesizing polyphenylalanine in vitro, in marked contrast to those from Streptomyces coelicolor (Fig. 3). In this respect, ribosomes from $S$. actuosus were indistinguishable from those of S. azureus (data not given).

More detailed examination of $S$. actuosus revealed that rRNA from this organism was not a substrate for the 'thiostrepton-resistance methylase' of $S$. azureus (data not given). This enzyme, which has been extensively purified (Thompson \& Cundliffe, 1981), is active on 23S rRNA from bacteria of a range of genera including Streptomyces, and its failure to act on rRNA from $S$. actuosus suggested that the latter organism might contain a similar methylase. This hypothesis was substantiated in a series of experiments in which post-ribosomal supernatant $(\mathrm{S} 100)$ of $S$. actuosus was employed as a source of methylase activity. The 
crucial experiment is summarized in Table 3. Ribosomal core particles from E. coli were incubated with $S$. actuosus $\mathrm{S} 100$ in the presence and absence of $S$-adenosylmethionine (SAM) as cofactor. Then, 'split proteins' were added back to the cores and the ability of the reconstituted ribosomes to bind $\left.{ }^{35} S\right]$ thiostrepton was assayed. In this way, the presence in $S$. actuosus of a methylase capable of rendering ribosomes refractory to thiostrepton was revealed. In other experiments, employing $\left[\right.$ methyl $\left.{ }^{3} \mathrm{H}\right] \mathrm{SAM}$ as cofactor and rRNA from $S$. coelicolor as substrate, we determined that crude methylase from $S$. actuosus introduced methyl groups exclusively into 23S rRNA with stoichiometry close to unity (data not given). We then subjected such RNA to enzymic digestion and analysis as described elsewhere (Cundliffe \& Thompson, 1979). During paper chromatography of the digest, the methylated residue co-migrated with $2^{\prime}$ - $O$-methyladenosine and, following elution, high-voltage paper electrophoresis at $\mathrm{pH} 3.5$ confirmed that this residue was a derivative of adenosine. Finally, failure of borate to mobilize it during high-voltage paper electrophoresis at $\mathrm{pH} 9 \cdot 3$ confirmed the absence of cis-hydroxyl groups on the pentose moiety. We concluded that the methylated residue introduced into $S$. coelicolor rRNA by $S$. actuosus extract was $2^{\prime}$ - $O$-methyladenosine.

\section{DIS CUSSION}

The present data clearly establish that nosiheptide and thiostrepton act similarly on bacterial ribosomes, although the latter drug binds with greater affinity to what may be a common target site. Thus, both drugs act on the 50S ribosomal subunit and both bind firmly to the complex of $23 \mathrm{~S}$ rRNA with ribosomal protein L11. Moreover, ribosomal binding of thiostrepton can be reduced to undetectable levels by the introduction into $23 \mathrm{~S}$ rRNA of a single methyl group catalysed by an enzyme present in organisms which produce either of these drugs. Presumably, such methylation occurs at a location physically adjacent to the site(s) at which nosiheptide and thiostrepton bind, although their precise relationship remains to be determined. It is also evident that these events occur in or near that region of the A site on the 50S ribosomal subunit into which factors EF-Tu and EF-G bind alternately during protein synthesis and in which GTP is hydrolysed (for a discussion, see Cundliffe, 1980). Moreover, this same ribosomal domain is implicated in the binding and action of stringent factor (Wagner \& Kurland, 1980).

Our conclusion that nosiheptide belongs (together with siomycin, sporangiomycin and thiopeptin) to the thiostrepton group of antibiotics rests not only on similarities in the modes of action of these drugs but also on the common mechanism of self defence employed by the respective producing organisms. Presumably, specific methylation of $23 \mathrm{~S}$ RNA perturbs the structure of the ribosome within the GTPase centre. The aim of future investigations will be to characterize such conformational changes.

This work was supported by a research project grant from the Medical Research Council. We thank Michael Stark for preparing stringent factor and examining the effects of nosiheptide on its function. We are also grateful to Dr J. Lunel of Rhône-Poulenc for providing nosiheptide*, to Dr G. Lancini of Gruppo Lepetit for thermothiocin, to Dr A. Tamura of Dainippon Ltd for actinotiocin, and to Miss B. Stearns of Squibb for thiostrepton.

* Nosiheptide (originally designated RP 9671 by Rhône-Poulenc) was the subject of U.S. Patent 3155581 , February 1962; published November 1964.

\section{REFERENCES}

Block, R. \& Haseltine, W. A. (1975). Purification and properties of stringent factor. Journal of Biological Chemistry 250, 1212-1217.
Bodley, J. W., LiN, L. \& Highland, J. H. (1970). Studies on translocation. VI: Thiostrepton prevents the formation of a ribosome- $G$ factor-guanine 
nucleotide complex. Biochemical and Biophysical Research Communications 41, 1406-1411.

Cundliffe, E. (1978). Mechanism of resistance to thiostrepton in the producing-organism Streptomyces azureus. Nature, London 272, 792-795.

CunDlFFe, E. (1980). Antibiotics and prokaryotic ribosomes: action, interaction, and resistance. In Ribosomes: Structure, Function and Genetics, pp. 555-581. Edited by G. Chambliss, G. R. Craven, J. Davies, K. Davis, L. Kahan \& M. Nomura. Baltimore: University Park Press.

Cundliffe, E. \& Dixon, P. D. (1975). Inhibition of ribosomal $\mathrm{A}$ site functions by sporangiomycin and micrococcin. Antimicrobial Agents and Chemotherapy $8,1-4$.

Cundliffe, E. \& Thompson, J. (1979). Ribose methylation and resistance to thiostrepton. Nature, London 278, 859-861.

Cundliffe, E., Dixon, P., Stark, M., Stöffler, G., Ehrlich, R., StöfFler-Meilicke, M. \& CANNon, M. (1979). Ribosomes in thiostrepton-resistant mutants of Bacillus megaterium lacking a single 50S subunit protein. Journal of Molecular Biology 132, 235-252.

Disk, J. \& LitTlechild, J. (1979). Purification of ribosomal proteins from Escherichia coli under non-denaturing conditions. Methods in Enzymology 59, 481-502.

Pedersen, F. S., Lund, E. \& KJeldgaard, N. O. (1973). Codon specific, tRNA dependent in vitro synthesis of ppGpp and pppGpp. Nature New Biology 243, 13-15.

PestKa, S. \& Brot, N. (1971). Studies on the formation of transfer RNA-ribosome complexes. XV. Effect of antibiotics on steps of bacterial protein synthesis: some new ribosomal inhibitors of translocation. Journal of Biological Chemistry 246, 7715-7722.

Prange, T., Ducruix, A., Pascard, C. \& Lunel, J. (1977). Structure of nosiheptide, a polythiazolecontaining antibiotic. Nature, London 265, 189190.

StaRK, M. \& Cundliffe, E. $(1979 a)$. Requirement for ribosomal protein BM-L11 in stringent control of
RNA synthesis in Bacillus megaterium. European Journal of Biochemistry 102, 101-105.

Stark, M. \& CundlifFe, E. $(1979 b)$. On the biological role of ribosomal protein BM-L11 of Bacillus megaterium, homologous with Escherichia coli ribosomal protein L11. Journal of Molecular Biology 134, 767-779.

Tamura, A., Furuta, R., Naruto, S. \& Ishil, H. (1973). Actinotiocin, a new sulphur-containing peptide antibiotic from Actinomadura pusilla. Journal of Antibiotics 26, 343-350.

Tanaka, T., Endo, T., Shimazu, A., Yoshida, R., SUZuki, Y., Otake, N. \& Yonehara, H. (1970a). A new antibiotic, multhiomycin. Journal of Antibiotics 23, 231-237.

Tanaka, T., Sakaguchi, K. \& Yonehara, H. $(1970 \mathrm{~b})$. On the mode of action of multhiomycin. 1. Effects of multhiomycin on macromolecular syntheses. Journal of Antibiotics 23, 401-407.

TANaKa, T., SAKaguChI, K. \& Yonehara, H. (1971). Inhibition by multhiomycin of T factor- and GTPdependent binding of phenylalanyl-tRNA to ribosomes and GTP hydrolysis associated with it. Journal of Biochemistry 69, 1127-1130.

Thompson, J. \& Cundliffe, E. (1980). Resistance to thiostrepton, siomycin and sporangiomycin in actinomycetes that produce them. Journal of Bacteriology 142, 455-461.

Thompson, J. \& Cundliffe, E. (1981). Purification and properties of an RNA methylase produced by Streptomyces azureus and involved in resistance to thiostrepton. Journal of General Microbiology 124, 291-297.

Thompson, J., Cundliffe, E. \& Stark, M. (1979). Binding of thiostrepton to a complex of 23S rRNA with ribosomal protein L11. European Journal of Biochemistry 98, 261-265.

Wagner, E. G. H. \& Kurland, C. G. (1980). Escherichia coli elongation factor $\mathrm{G}$ blocks stringent factor. Biochemistry 19, 1234-1240.

Weisblum, B. \& DEMOHN, V. (1970). Inhibition by thiostrepton of the formation of a ribosome-bound guanine nucleotide complex. FEBS Letters 11 , 149-152. 